\title{
Abortion in the classical world
}

\section{Lesley Smith}

Tutbury Castle, Tutbury, UK

Correspondence to

Ms Lesley Smith, Tutbury Castle, Tutbury, Staffordshire DE13 9JF, UK;

info@tutburycastle.com

Received 26 January 2012

Accepted 26 January 2012

\section{Oaths and ethics}

Even someone with only the most basic understanding of medical history knows that Hippocrates is viewed as the father of medicine and that the Hippocratic Oath forbids a physician from giving a woman an abortive remedy or giving the woman the means of procuring an abortion.

The translation of the Hippocratic Oath has been the subject of much debate as some academics claim that translations over the years through the medieval period and beyond have been general rather than specific. It is important to appreciate that these broad translations fitted nicely into ecclesiastical teachings in the medieval period giving dogma the extra foundation of classical teachings. Some may argue this is a cynical view but what is undeniable according to historians such as Professor John Riddle is that the line on abortion in the original Hippocratic Oath literally translates that the physician must not "... give a suppository to cause an abortion", which in a broader sense has been offered as a prohibition on abortion caused by any means. Interestingly, this line directly follows a statement that swore its tenets not to advise on the use of poisons or to administer any.

It is believed that this oath was taken by ancient physicians but we do not know precisely who took the oath and how many followed the teachings of Hippocrates. A Roman medical writer in the 1 st century $\mathrm{AD}$, who had the marvellous name of Scribonius Largas, wrote "Hippocrates, who founded our profession, laid the foundation for our discipline by an oath, in which it was proscribed not to give to a pregnant woman a kind of medicine that expels an embryo".

What is undeniable in this medical history debate is that abortion was discussed in the 5 th century $\mathrm{BC}$ and was considered a medical and moral matter that should have boundaries and ethics applied to it.

\section{Methods and medicines}

Greco-Roman medical texts discussed late-term abortions by the use of medicines or quite aggressive forms of manipulation that were also recognised as possibly dangerous to the mother. Although surgical procedures for abortion are referred to in early works, most scholars agree this was only resorted to in the most desperate of situations. There are existing texts and one can just imagine the level of brutality that would have been employed to obtain this result, no doubt frequently resulting in the death of the woman at the time of the procedure or shortly afterwards. It is hardly surprising it was avoided unless in a final attempt to save life.

A really early example of suggested strenuous physical exercise to bring on an abortion was known as the Lacedaemonian leap in which a woman was advised to leap in the air and have her heels strike her buttocks. This may be found in a medical treatise believed to have been written by Hippocrates entitled On the Nature of the Child. The strike and angle the woman attained at the moment of the blow was believed to open the cervix and force the embryo out. In the 20th century there is evidence that frightened young women following unprotected sex would run up and down stairs, lift weights or jump up and down vigorously in an attempt to "bring on a period".

In the 2 nd century AD, Soranus, who was the leading writer in the classical world on obstetrics and gynaecology, specifically states he will not give an abortive. $\mathrm{He}$ writes that drug-induced abortions are dangerous and yet later gives recipes that are for drug abortifacients and points out in his texts that abortions undertaken in the first 30 days following conception are relatively easy and less dangerous than late-term abortions. This is all very confusing to the reader as Soranus contradicts himself. One explanation could be what is meant by abortion. At which point did our ancestors believe that the fetus was 'quick' (i.e. living)? Aristotle suggested that life in the sense of animation happened 40 days after conception for a male fetus and 90 days after conception for a female fetus. 
Even more importantly, is the drug given purely to cause menstruation to commence rather than to force a termination of pregnancy? That moral difference in terms of intent is vitally important when considered by the ecclesiastical courts in later centuries.

The link between menstruation and fertility appears in the most ancient of references and a woman's ability to bear a child for her family was so important that it is hardly surprising that medicines that controlled the menstrual cycle of women feature strongly in medical texts and oral tradition stretching back to ancient times.

There is evidence of early-term abortifacients. Soranus offers a range of solutions from laxatives to pungent foods. Soaking for long periods of time in a warm, not hot, bath after drinking alcohol is the next step to try. If this didn't work then a poultice of rue and olive oil could be applied, or wormwood and honey. Pessaries were certainly used and bleeding was also practised, followed - it was recommended - by heavy physical exercise. Potions of wormwood and rue mixed with wine and honey and bitter herbs crushed into the draught were one of the final options, as this involved actually drinking a medicine as opposed to laying it on the skin or introducing it into the vagina.

The choices offered in this article of medicines, manipulation and surgery indicate that even in ancient times women needed termination medical services, which at times cost them their lives. The writings of Greco-Roman physicians also prove that abortion was at the heart of much medical ethical debate.

\section{Future articles}

The next article in this series will consider the question "Why did King Henry VIII marry Catherine Parr?".

\section{About the author}

Lesley Smith is currently a postgraduate student in the Centre for the History of Medicine of the University of Birmingham, where she is developing a $\mathrm{PhD}$ in obstetrics and gynaecology in early modern Britain. She holds an honorary degree for "services to history”. She makes 200-300 public appearances a year and also works as a TV historian in the UK and abroad including the USA. Lesley is also Curator of Tutbury Castle in Staffordshire and is a member of the Society of Apothecaries of London and the Society of Medical Writers. She has recently been appointed a Fellow of the Society of Antiquaries of Scotland.

Acknowledgement The author would like to thank Dr G Williams, British Museum, London, UK for his help and advice.

Competing interests None.

Provenance and peer review Commissioned, internally peer reviewed.

\section{References}

1 Riddle JM. Contraception and Abortion from the Ancient World to the Renaissance. Cambridge, MA: Harvard University Press, 1992.

2 Tannahill R. Sex in History. London, UK: Book Club Associates, 1980.

3 Rattray Taylor G. Sex in History. London, UK: Thames and Hudson, 1951.

4 French R. Medicine Before Science: The Business of Medicine from the Middle Ages to the Enlightenment. Cambridge, UK: Cambridge University Press, 2003.

5 Williams J, Cheesman C (eds). The British Museum Classical Love Poetry. London, UK: The British Museum Press, 2004.

6 Boorde A. The Fyrst Boke of the Introduction of Knowledge. A Compendyous Regyment; or, A Dyetary of Helth Made in Mountpyllier. Barnes in the Defence of the Berde. London, UK: Adamant Media Corporation, 2001.

7 Green MH (ed.). The Trotula. Philadelphia, PA: University of Pennsylvania Press, 2001. 